\title{
Boron Content in Shallow Ground Water of Andhra Pradesh And Telangana States, India
}

\author{
K. Siva Sankar, J.S. Bhargav, Sibasree Karmakar \\ Chemical Division, Geological Survey of India, Southern Region, Hyderabad
}

\begin{abstract}
National Ground Water Monitoring wells in erstwhile Andhra Pradesh (presently Andhra Pradesh and Telangana States) were used to create a baseline data on content of boron in the phreatic zone. The study area is spread over by about 2.7 lakh $\mathrm{sq} \mathrm{km}$ and has three distinct hyrogeological formations-Consolidated, Semiconsolidated and Unconsolidated formations. In the study 618 dugwells were monitored for various chemical parameters including boron. The data obtained was classified formation wise and discussed on the basis of boron tolerance of various crops.
\end{abstract}

Key Words: Andra Pradesh, Groundwater, Hydrogeological formations, Boron.

\section{Introduction}

The drastic fall in food production scenario in the world is normally thought to be driven by the climate change and depletion in water resources. In India, more specifically in Andhra Pradesh, where majority of irrigational practices are dependent on ground water, the situation has worsened. Under this scenario plant diseases either due to deficiency or due to excessive dose of micro or macro nutrient is unwarranted. Boron is a chemical element often found in rocks and soil. It is a minor constituent of most waters. Boron is important in agriculture. Small amounts of Boron are essential to plant nutrition. Greater concentrations of Boron in soil and irrigation waters are harmful. Citrus fruit trees and wall nut trees are found to be most sensitive to excess boron. Boron has been found to be potentially harmful in drinking water. The Bureau of Indian Standards Prescribes a desirable limit of $0.5 \mathrm{mg} / \mathrm{l}$ and a maximum permissible limit of $1.0 \mathrm{mg} / \mathrm{l}$ in the absence of alternative source for boron concentrations in drinking water (BIS,2012). Boron forms an extensive series of chemical complexes, but water analysis report boron concentration in terms of elemental boron (B).

\section{PURPOSE OF THE STUDY}

In view of the impact of the excess of boron in ground water on plant and human physiology, it was felt necessary to generate a baseline information about the content and condition of the environment for the occurrence of boron in shallow ground water resources in Andhra Pradesh.

\section{AQUIFERS MOST SENSITIVE TO BORON CONTAMINATION:}

Boron concentrations in ground water have been found to be greater in reducing environments. Therefore deeper wells in aquifers of Cretaceous, Precambrian formations and buried glacial drift are sensitive to higher levels of boron. Occurrence of boron, along with calcium, sodium. potassium and strontium points towards increased residence time, or older ground water. Contrarily, near-surface aquifers, such as the water table aquifer, have low median concentrations of boron. These aquifers are sensitive to contamination with boron only if there is a source of boron in the unsaturated zone. Under these conditions, if there is a man-made source of boron available for leaching, the shallow ground water of a water table aquifer would be sensitive to boron contamination.

\section{ANTHROPOGENIC SOURCES FOR BORON IN GROUND WATER:}

Anthropogenic sources of boron are considered to contribute a lesser amount to the environment than natural processes. Anthropogenic sources of boron are agricultural, waste and fuel wood burning, power generation using coal and oil, glass product manufacture, use of borates/ perborates in the home and industry, borate mining/processing, leaching of treated wood/paper, and sewage/sludge disposal of boron. Borates in detergents, soaps, and personal care products can also contribute to the presence of boron in water.

\section{NATURAL SOURCES FOR BORON IN GROUND WATER:}

Boron occurs in combination in several silicates, the chief of these being tourmaline, axinite and datolite. The principle forms in which boron occurs in nature are, however, as borates, and these are of great industrial importance. The chief borates Boric acid, $\left(\mathrm{H}_{3} \mathrm{BO}_{3}\right)$, Borax $\left(\mathrm{Na}_{2} \mathrm{~B}_{4} \mathrm{O}_{7} \cdot 10 \mathrm{H}_{2} \mathrm{O}\right)$, Kernite, $\mathrm{Na}_{2} \mathrm{~B}_{4} \mathrm{O}_{7} \cdot 4 \mathrm{H}_{2} \mathrm{O}$, Colemanite $\left(\mathrm{Ca}_{2} \mathrm{~B}_{6} \mathrm{O}_{11} \cdot 5 \mathrm{H}_{2} \mathrm{O}\right)$, Ulexite $\left(\mathrm{NaCaB}_{5} \mathrm{O}_{9} .8 \mathrm{H}_{2} \mathrm{O}\right)$, Magnesium Borate and Chloride Boracite $\left(\mathrm{Mg}_{3} \mathrm{~B}_{7} \mathrm{O}_{13} \mathrm{Cl}\right)$. Boron is a naturally occurring compound, usually found in various inorganic forms in 
sediments and sedimentary rocks. Presence of boron in water, soil, and air originates from both natural and anthropogenic sources. Natural weathering of boron-containing rocks is thought to be the primary source of boron compounds in water and soil (Butterwick et al., 1989). Releases to air from oceans, volcanoes, and geothermal steam are other natural sources of boron in the environment (Graedel, 1978).

\section{GEOCHEMISTRY OF BORON:}

Most boron compounds are soluble in water while the solubility of elemental boron is very low. Due to the high water-solubility of the environmentally-relevant boron minerals, Rai et al. (1986) concluded that it is unlikely that mineral equilibria will control the fate of boron in water. Boron compounds such as borax rapidly hydrolyze to form a boric acid-borate mixture. Boric acid is a weak acid that exists primarily in its unionized form at $\mathrm{pH}$ below 7. Borate and boric acid establish an equilibrium reaction in water that is dependant on the $\mathrm{pH}$.

$$
\mathrm{Na}_{2} \mathrm{~B}_{4} \mathrm{O}_{7} \cdot 10 \mathrm{H}_{2} \mathrm{O}+\mathrm{H}_{2} \mathrm{O} \rightarrow \mathrm{B}(\mathrm{OH})_{3}+\mathrm{H}_{2} \mathrm{O} \times \mathrm{B}(\mathrm{OH})_{4}+\mathrm{H}^{+} \mathrm{pKa}=9.14
$$

\section{TOXICITY OF BORON: TOXICITY OF BORON IN PLANTS}

Boron problems originating from the water are probably more frequent than those originating in the soil. Boron toxicity can affect nearly all crops but, like salinity, there is a wide range of tolerance among crops. Boron toxicity symptoms normally show first on older leaves as a yellowing, spotting, or drying of leaf tissue at the tips and edges. Drying and chlorosis often progress toward the center between the veins (interveinal) as more and more boron accumulates with time. Most crop toxicity symptoms occur after boron concentrations in leaf blades exceed $250-300 \mathrm{mg} / \mathrm{kg}$ (dry weight) but not all sensitive crops accumulate boron in leaf blades. For example, stone fruits (peaches, plums, almonds, etc.), and pome fruits (apples, pears and others) are easily damaged by boron but they do not accumulate sufficient boron in the leaf tissue for a leaf analysis to be a reliable diagnostic test. With these crops, boron excess must be confirmed from soil and water analyses, tree symptoms and growth characteristics. The salinity laboratory of United States of America developed a rating table that indicates the permissible Boron concentrations in irrigation water for three classes of plants.

Table 1 - Rating Of Irrigation Water For Various Crops, On The Basis Of Boron Concentration In Water.

\begin{tabular}{|l|l|l|l|l|}
\hline \multicolumn{2}{|c|}{ Class of wate } & Sensitive crops (mg/l) & Semi tolerant crops (mg/L) & Tolerant crops(mg/l) \\
\hline Rating & Grade & \multicolumn{3}{l|}{} \\
\hline 1 & Excellent & $<0.33$ & $<0.67$ & $<1.0$ \\
\hline 2 & Good & $0.33-0.67$ & $0.67-1.33$ & $1.0-2.0$ \\
\hline 3 & Permissible & $0.67-1.0$ & $1.33-2.0$ & $2.0-3.0$ \\
\hline 4 & Doubtful & $1.0-1.25$ & $2.0-2.5$ & $3.0-3.75$ \\
\hline 5 & Unsuitable & $>1.25$ & $>2.5$ & $>3.75$ \\
\hline
\end{tabular}

\section{TOXICITY OF BORON ON HUMANS:}

According to Stokinger (1981), the lowest reported lethal doses of boric acid are $640 \mathrm{mg} / \mathrm{kg}$ of body weight (oral), $8600 \mathrm{mg} / \mathrm{kg}$ of body weight (dermal), and $29 \mathrm{mg} / \mathrm{kg}$ of body weight (intravenous injection). Similarly Goldbloom \& Goldbloom (1953) reported four cases of boric acid poisoning and reviewed an additional 109 cases in the literature. The four cases were infants exposed to boric acid by repeated topical applications of baby powder. Toxicity was manifested by cutaneous lesions (erythema over the entire body, excoriation of the buttocks, and desquamation), gastrointestinal disturbances, and seizures. The other symptoms observed were disorders in the Central Nervous System (CNS). In general, boric acid caused chemical irritation primarily at sites of application and excretion and in organs with maximum boron concentrations. The most common CNS findings were oedema and congestion of the brain and meninges. Other common findings included liver enlargement, vascular congestion, fatty changes, swelling, and granular degeneration. Although the function of boron remains undefined, boron is becoming recognized as an element of potential nutritional importance because of the findings from human and animal studies (Nielsen, 1989, 1994; Nielsen et al.,1990,; Penland, 1994). Bureau of Indian standards (BIS) specified $0.5 \mathrm{mg} / \mathrm{l}$ boron as desirable limit and $1.0 \mathrm{~S} \mathrm{mg} / \mathrm{l}$ as maximum permissible for boron in drinking water.

\section{GENERAL FEATURES OF STUDY AREA:}

Andhra Pradesh which covers an area of 2,75,068 Sq.Km lies between north latitudes $12^{0} 37^{\prime}$ and $19^{0} 54^{\prime}$ east latitudes $76^{0} 50^{\prime}$ and $84^{0} 50^{\circ}$.The state receives about $66 \%$ of the rain fall from southwest monsoon, about $25 \%$ from northeast monsoon and the remaining $9 \%$ of the rainfall is received during summer and winter months. The state is occupied by various types of soils which include black cotton, lateritic, red sandy, alluvial soils. 


\section{HYDROGEOLOGICAL ENVIRONMENT:}

The state is underlain by various geological formations from the oldest Archaen rocks to the Recent Alluvium. The Archaens, which present, the shield, over which the rocks belonging to Pre-Cambrian, Gondwana, Mio-Pliocene and sub-Recent to Recent ages together with Deccan traps overlie in various parts of the state. All the geological formations occurring in the state can be divided into consolidate, semi-consolidate and unconsolidated formations (Sudarshan, G and Rao,P.N,2004).

1. Consolidated hard rocks occupying nearly $84 \%$ of the state comprise rocks of Archaen age, lime stones, quartzites and slates of Pre-Cambrian age, Infra and massive Deccan Traps of Cretaceous to Eocene age.

2. The semi consolidated sedimentary formations comprising Gondwanas, Infra and Inter trappeans and Rajahmundry sandstones.

3. The unconsolidated alluvial formations comprising coastal deltaic and river alluvium of sub-Recent to Recent age.

\section{SAMPLING LOCATIONS}

In the present study Network Hydrograph stations (NHS) mostly comprising of dugwells tapping the phreatic aquifer are confined to village limits, which are used for domestic purposes by the local public. Some of these are community wells and the rest belong to private individuals. The water quality monitoring which is carried out once in a year (premonsoon) was conducted during May 2006. Fig.1 shows the locations of the NHS stations.

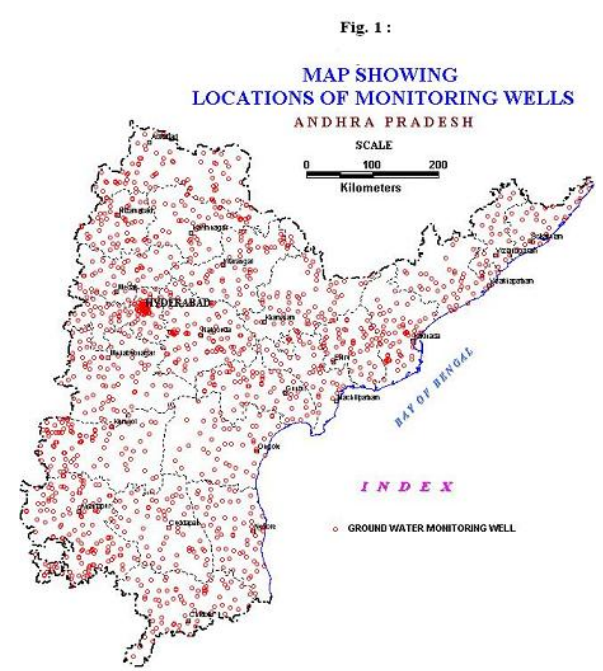

SAMPLING AND METHODOLOGY:

Ground water samples were collected from 618 Ground Water Monitoring Wells of Andhra Pradesh during pre monsoon. Samples were analysed for Boron with using Inductively Coupled Plasma Spectrometer (ICP-AES), Model 1000- IV of Shimadzu make.

\section{Results And Discussions:}

Results of the chemical analysis of water samples in different geological formations of Andhra Pradesh are presented in Table no-2.

Table 2: Range of pH, E.C and boron values in different geological formations.

\begin{tabular}{|l|l|l|l|l|l|}
\hline Sl.No & Formation & No. of Samples & pH range & E.C range & B(mg/l $)$ \\
\hline 1 & Granite \& Gneisses & 331 & $4.76-9.9$ & $309-12400$ & $0-2.58$ \\
\hline 2 & Khondalite & 50 & $6.99-8.91$ & $105-4410$ & $0-0.77$ \\
\hline 3 & Charnokites & 4 & $7.08-7.85$ & $225-3575$ & $0-0.12$ \\
\hline 4 & Limestone & 23 & $7.14-9.9$ & $637-3900$ & $0.02-1.13$ \\
\hline 5 & Laterite & 7 & $7.05-8.19$ & $365-1780$ & $0-0.26$ \\
\hline 6 & Phyllite & 4 & $6.95-8.54$ & $655-2085$ & $0-0.09$ \\
\hline 7 & Quartzite & 10 & $7.64-9.9$ & $375-3560$ & $0-0.35$ \\
\hline 8 & Deccan Traps & 20 & $7.0-8.24$ & $335-1820$ & $0-0.8$ \\
\hline 9 & Shale & 23 & $7.1-8.3$ & $350-7580$ & $0-1.08$ \\
\hline 10 & Schist & 16 & $4.76-9.66$ & $90-8650$ & $0-1.74$ \\
\hline 11 & Sandstones & 45 & $6.48-8.74$ & $240-3460$ & $0-0.7$ \\
\hline 12 & Alluvium & 85 & $7.06-9.25$ & $440-7430$ & $0-1.3$ \\
\hline
\end{tabular}


About $7.8 \%$ of the samples contain boron concentration more than $0.5 \mathrm{mg} / \mathrm{l}$ (desirable permissible limit of BIS) and $1.2 \%$ of the samples contain boron more than $1.0 \mathrm{mg} / \mathrm{l}$ (maximum permissible limit of BIS). These high boron concentrations samples were observed in granite, limestone, shale, schist and alluvial aquifers. From the results it can be seen that high values of boron are associated with high $\mathrm{pH}$ and high mineralization. This is in accordance to the geochemical equation described earlier. In view of the toxic effects of boron on plants, the ground water samples were classified according to the general tolerance levels of a majority of crops to the boron concentrations. Fig.3 shows percentage of samples suitable for various boron tolerant crops in Andhra Pradesh. Most of the waters are suitable for crops whose sensitivity ranges from moderately sensitive to very tolerant towards boron.
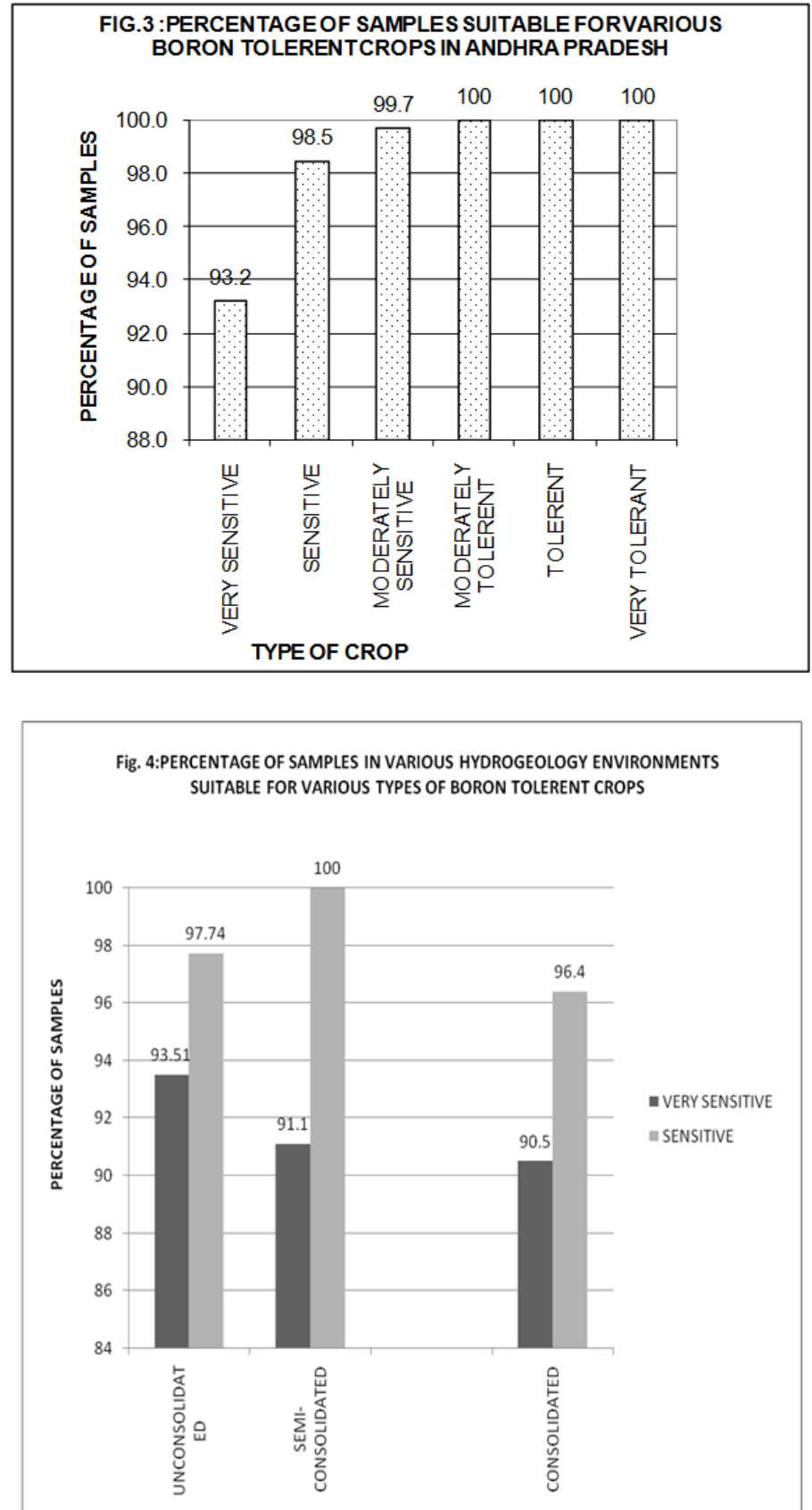

The results were further analysed to know the suitability of waters yielding from various formations for the tolerance of very sensitive and sensitive crops towards boron. Fig.4 presenting the percentage of samples suitable for very sensitive and sensitive crops for boron in different hydrogeological formations revel that the waters unsuitable for boron tolerant crops have been observed to be more from consolidated formations. 


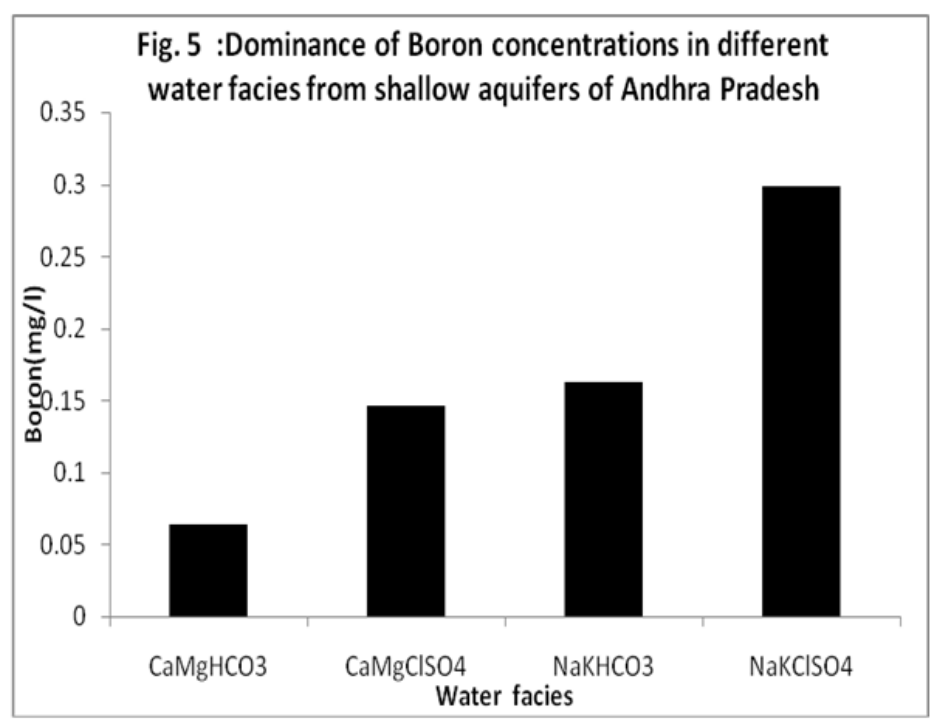

Further the data of all the samples was analysed and the predominant facies was determined. Fig. 5 shows the average boron concentration of all the samples of each facies determined. It is apparent that the boron concentration is highest in $\mathrm{NaKClSO} 4$ type waters which reflect discharge area. Boron appears to leach into ground waters under highly mineralised, high $\mathrm{pH}$ and reduced conditions in the study area.

\section{Conclusions}

High boron concentrations $(>0.5 \mathrm{mg} / \mathrm{l}$ and $>1.0 \mathrm{mg} / \mathrm{l}$ detected in $7.8 \%$ and $1.2 \%$ of the samples respectively ) were mainly observed in granite, limestone, shale, schist and alluvial aquifers. Most of the waters are suitable for crops whose sensitivity ranges from moderately sensitive to very tolerant towards boron. Further it is apparent that the boron concentration is highest in $\mathrm{NaKClSO}_{4}$ type waters, which reflect the location of the well to be in a discharge area. Therefore Boron appears to leach into ground waters under highly mineralised, high $\mathrm{pH}$ and reduced conditions in the study area.

\section{References}

[1] APHA, (2000). Standard Methods for the examination of water and waste water (20 ${ }^{\text {th }}$ edition) Washigton, D.C American Public Health Association.

[2] Bureau of Indian standards drinking water specifications; IS 10500:2012, New Delhi.

[3] Butterwick, L., N. de Oude, and K. Raymond. 1989. Safety assessment of boron in aquatic and terrestrial environments. Ecotoxicol. Environ. Safety 17:339-371 (as cited in ATSDR, 1992)

[4] Goldbloom RB, Goldbloom A (1953) Boric acid poisoning: Report of four cases and a review of 190 cases from the world literature. Journal of pediatrics, 43:631-643.

[5] Graedel, T.E. 1978. Inorganic elements, hydrides, oxides, and carbonates. In: Chemical Compounds in the Atmosphere. New York, NY: Academic Press. pp. 35-49 (as cited in ATSDR, 1992).

[6] Nielsen FH (1989) Dietary boron affects variables associated with copper metabolism in humans. In: Aulse M et al., eds. Proceedings of the 10th international trace element symposium. Vol. 4. Jena, Friedrich-Schiller-Universität, pp. 1106-1111. 28.

[7] Nielsen FH (1994) Biochemical and physiological consequences of boron deprivation in humans. Environmental health perspectives, 102 (Suppl. 7):59-63.

[8] Nielsen FH, Mullen LM, Gallagher SK (1990) Effect of boron depletion and repletion on blood indicators of calcium status in humans fed a magnesium-low diet. Journal of trace elements in experimental medicine, 3:45-54.

[9] Penland JG (1994) Dietary boron, brain function and cognitive performance. Environmental health perspectives, 102 (Suppl. 7):6572.

[10] Rai, D., J.M. Zachara, A.P. Schwab, et al. 1986. Chemical attenuation rates, coefficients, and constants in leachate migration. Vol. 1. A critical review. Report to Electric Power Research Institute, Palo Alto, CA by Battelle, Pacific Northwest Laboratories, Richland, WA. Research Project 2198-1 (as cited in ATSDR, 1992).

[11] Stokinger HE (1981) Boron. In: Clayton GD, Clayton FE, eds. Patty's industrial hygiene and toxicology. Vol. 2B. Toxicology, 3rd ed. New York, NY, John Wiley \& Sons, pp. 2978- 3005.

[12] Sudarshan,G and Rao,P.N (2004) Groundwater in Andhra Pradesh( A report), Central Groundwater Board, Southern Region, Government of India. 